\title{
Occurrence of Aflatoxin Producing Mould in Irvingia Gabonensis (Bush Mango) Seeds Sold Within Jos Metropolis
}

\author{
Katnap Ramnan Selvyat ${ }^{1,}$, , Arome A. F. ${ }^{1}$, Zakari H. ${ }^{1}$, Juliet Okechalu ${ }^{1}$, Nanbol K. K. ${ }^{2}$, \\ Kumzhi P. R. ${ }^{3}$, Joseph Aje Anejo-Okopi ${ }^{1}$ \\ ${ }^{1}$ Department of Microbiology, Faculty of Natural Sciences, University of Jos, Jos, Nigeria \\ ${ }^{2}$ Department of Plant Science and Technology, Faculty of Natural Sciences, University of Jos, Jos, Nigeria \\ ${ }^{3}$ Department of Nursing Science, Faculty of Medical Sciences, University of Jos, Jos, Nigeria
}

Email address:

katsonworld@gmail.com (K. R. Selvyat)

${ }^{*}$ Corresponding author

\section{To cite this article:}

Katnap Ramnan Selvyat, Arome A. F., Zakari H., Juliet Okechalu, Nanbol K. K., Kumzhi P. R, Joseph Aje Anejo-Okopi. Occurrence of Aflatoxin Producing Mould in Irvingia gabonensis (Bush Mango) Seeds Sold Within Jos Metropolis. American Journal of Biomedical and Life Sciences. Vol. 5, No. 5, 2017, pp. 92-95. doi: 10.11648/j.ajbls.20170505.12

Received: February 23, 2017; Accepted: March 21, 2017; Published: October 18, 2017

\begin{abstract}
This study was conducted to determine the occurrence of aflatoxin producing mould in Irvingia gabonensis (Bush Mango) seeds sold within Jos metropolis. The total fungal load per sample was gotten from plate count and expressed as Colony Forming Units per gram of sample (cfu/g). The aflatoxigenicity of the fungal isolates was also evaluated on Coconut Extract Agar (CEA) by exposing the reversed side of plates to $365 \mathrm{~nm}$ ultraviolet light. The result showed that mean fungal count of I. gabonensis ranges from $3.2 \times 10^{6}$ to $4.0 \times 10^{6} \mathrm{cfu} / \mathrm{g}$. The fungi that were implicated for the contamination of the $I$. gabonensis include: Aspergillus flavus, Aspergillus fumingatus, Aspergillus parasiticus, Aspergillus niger, Peneillium chrisogenu, Verticelium leceanii, Rhizopus oryzea, Fusarium sporotrichoides and yeast. Strains of V. leceanii, yeast and A. flavus were the most predominant at $47.9 \%, 37.5 \%$ and $35.4 \%$ respectively. By a way of comparison, the result also showed that Bush Mango seeds from Terminus and Gadabiyu were the most contaminated, followed by Faringada and then Angwa Rukuba. Out of the 39 Aspergillus species isolated, only 4 strains exhibited aflatoxin producing potential. The presence of these aflatoxigenic mould on I. gabonensis seeds presents high health risk and calls for more regulations and periodical assessment of Bush Mango seeds sold in open markets.
\end{abstract}

Keywords: Aflatoxigenic, Fungi, Irvingia Gabonensis, Mycotoxin

\section{Introduction}

Fungi are ubiquitous which make them major spoilage agents of agricultural crops, foods and feedstuffs, that results in the reduction of postharvest quality of crops. Their occurrence in food pose potential health hazard to human beings and animals, due to their ability to produce poisonous secondary metabolites (Mycotoxin), that when ingested have enormous public health significant (Williams et al., 2004; Miller et al., 1996). Humans can ingest aflatoxins by the periodic consumption of contaminated food. Aflatoxin have been seen to occur in different kind of foodstuffs, such as fruits, spices, cereals, oils, milks, meat, vegetables, etc. (Dor et al., 2011).

Irvingia gabonensis (Bush mango), also known as wild mango, African mango is commonly called 'Ogbono' in Igbo and 'Apon' in Yoruba (Okafor, 1978). It produces edible fruits and seeds. The dried seeds of Irvingia gabonensis is widely consumed by humans in Nigeria as a good thickener for soup. Dried Irvingia. gabonensis seeds has low water activity however, poor handling and storage, combination of environmental factors and continual exposure in the market 
could predispose aflatoxigenic contaminants to it (Shaltout et al., 1999).

One of the most important mycotoxins of health significance is aflatoxin. The toxins are primarily produced by Aspergillus flavus, Aspergillus parasiticus and Aspergillus nominus. Contamination of I. gabonensis seeds with these aflatoxigenic mould will pose a very serious health hazard because of its wide consumption by humans/ animals. (Leitao et al., 1988; Dorner, 2002; Yiannikouris and Jouncy, 2002). Aflatoxin are chemically and biologically active by-products produced by fungi growth naturally in wide range of plant products when conditions that support growth are present. The toxins are mutagenic, immunotoxic, carcinogenic, tetratoxigenic and nephrotoxic, capable of causing acute and chronic effects ranging from disorder of the central nervous system, cardiovascular/pulmonary system and death (Georggiet et al., 2000; Hussein and Brasel, 2011; Bhat and Vasanthi, 2003). The health implication of mycotoxigenic fungal-contaminants is often very serious and apparently not known to consumers, since mycotoxins might have been produced but yet invisible to naked eyes. The mould might be killed by heat during processing but the mycotoxins can remain undestroyed in the final products thereby posing high health risk to the consumers of such products (Smith et al., 1994).

It has been established by the United Nation Food and Agricultural Organisation that approximately $25 \%$ of the world's foods are contaminated with mycotoxins, especially aflatoxins (Smith et al., 1994). About 4.5 billion people mostly in developing countries are at risk of chronic exposure to aflatoxins from contaminated food crops (Oyebaji et al., 2013; Shuaib et al., 2010). Due to these, the level of aflatoxins and similar toxic substances in foodstuffs have to be evaluated closely and to be continually kept under control. Else, related health risk like acute and chronic aflaintoxications and even death will always be an issue. (Becer and Filazi, 2010). The analytical methods used in the developed countries are quite sensitive and reliable but very expensive to employ in developing countries like Nigeria. This have presented the need for aflatoxin detection methods that are reliable but inexpensive, so that it can be conducted with a level of technical skill acquirable in developing countries. If regularly and appropriately done, will reduce cases of intoxication and help set standards for agricultural products like Irvingia gabonensis seed which is widely consumed in Nigeria. This has raised major concerns among researchers and there is need for mycotoxin surveillance because of its wide occurrence in contaminated commodities (Negedu et al., 2011).

\section{Materials and Methods}

\subsection{Sample Collection}

A total of 48 I. gabonensis seed samples were randomly purchased from hawkers and stationary sellers in the major markets within Jos metropolis. The markets include
Faringada, Angwa rukuba, Terminus and Satelite markets. Successively, 12 samples each were obtained in clean polythene bags at different sales points in the markets during the rainy season at four weeks interval, and transported to National veterinary Research Institute Microbiology laboratory Vom for appropriate analysis.

\subsection{Mycological Analysis}

The mycological analysis of the collected sample was carried out following standard method of Samson (2000). $10 \mathrm{~g}$ of the pulvarised dried I. gabonensis seeds was weighed and homogenously mixed in $90 \mathrm{ml}$ of sterile distilled water. It was then serially diluted to 5 folds and $0.1 \mathrm{ml}$ of the resultant solution was spread plated on Sabaroud Dextrose Agar (SDA) incorporated with $40 \mu \mathrm{g} / \mathrm{ml}$ chloramphenicol to prevent the growth of bacterial contaminants if present. Enumeration of colonies (cfu/g) was done after 7days of incubation at $27^{\circ} \mathrm{C}$. Distinct colonies were then subcultured on fresh SDA media to obtain pure isolates for further examination.

The fungal isolates were identified using cultured, macroscopic and microscopic morphologies, and comparison with standard representative of species in relevant fungal atlas (Samson, 2000; Barnett et al., 1998).

\subsection{Screening for Aflatoxigenic Fungi}

Screening for aflatoxin production potentials was carried on coconut extract agar (CEA) with $40 \mu \mathrm{g} / \mathrm{ml}$ chloramphenicol to suppress bacterial growth, following standard methods (Davis et al., 1987). All the pure fungal isolates were inoculated on $\mathrm{CEA}$ and incubated at $27^{\circ} \mathrm{C}$ for 5 days. The aflatoxin producing potential of the isolates was determined by observing reversed side of plates under $365 \mathrm{~nm}$ ultraviolet lamb. Using noninnoculated CEA medium as control, the emission of a characteristic blue fluorescence confirmed the presence of aflatoxin producing potentials of the isolates.

\section{Results}

The result showed fungal contamination of Irvingia gabonensis seeds which result in a significant total fungal load which ranges from 0.00 to $6.8 \times 10^{6} \mathrm{cfu} / \mathrm{g}$. (Table 1 ). The result also showed that the $I$. gabonensis seed obtained from Terminus and Gadabiyu had the highest mean fungal load of $4.0 \times 10^{6} \mathrm{cfu} / \mathrm{g}$, while samples from Angwa Rukuba had the lowest mean fungal load.

Nine fungal species were isolated from the I. gabonensis as presented in table $2.33 .8 \%$ of the fungal isolated were Aspergillus species which included $A$. flavus, A. fumigatus, $A$. parasiticus and $A$. niger. Other fungal genera isolated were Penecillium chrisogenu, Verticelium leceanii, Rhizopus oryzea, Fusarium sporotrichoides and yeast.

The result also showed that out of 39 Aspergillus species isolated, 17 were $A$. flavus, 9 were $A$. fumigatus, 5 were $A$. parasiticus and 8 were $A$. niger (Table 3 ). Only $2 A$. flavus strains exhibited aflatoxin producing potential while one each 
for A. fumigatus and A. niger respectively. None of the $5 \mathrm{~A}$. parasiticus strains showed aflatoxin producing potential.

Table 1. Mean Fungal Load of Irvingia gabonensis (Bush Mango).

\begin{tabular}{lllll}
\hline Sample No. & Terminus & Faringada & Angwa Rukuba & Gadabiyu \\
\hline 1 & $6.1 \times 10^{6}$ & $1.6 \times 10^{6}$ & $1.2 \times 10^{6}$ & $1.5 \times 10^{6}$ \\
2 & $1.9 \times 10^{6}$ & $3.0 \times 10^{6}$ & $3.0 \times 10^{6}$ & $5.3 \times 10^{6}$ \\
3 & $6.4 \times 10^{6}$ & $6.0 \times 10^{6}$ & $5.2 \times 10^{6}$ & $5.3 \times 10^{6}$ \\
4 & $4.4 \times 10^{6}$ & $1.0 \times 10^{6}$ & $4.1 \times 10^{6}$ & $4.2 \times 10^{6}$ \\
5 & $3.0 \times 10^{6}$ & $3.4 \times 10^{6}$ & $2.0 \times 10^{6}$ & $2.2 \times 10^{6}$ \\
6 & $2.9 \times 10^{6}$ & $4.6 \times 10^{6}$ & $1.7 \times 10^{6}$ & $1.5 \times 10^{6}$ \\
7 & $3.1 \times 10^{6}$ & $3.8 \times 10^{6}$ & $1.3 \times 10^{6}$ & $3.6 \times 10^{6}$ \\
8 & $6.2 \times 10^{6}$ & $6.8 \times 10^{6}$ & $6.8 \times 10^{6}$ & $6.7 \times 10^{6}$ \\
9 & $1.5 \times 10^{6}$ & $4.7 \times 10^{6}$ & $2.2 \times 10^{6}$ & $6.8 \times 10^{6}$ \\
10 & $3.2 \times 10^{6}$ & $3.7 \times 10^{6}$ & $1.5 \times 10^{6}$ \\
11 & $5.0 \times 10^{6}$ & $6.8 \times 10^{6}$ & $2.0 \times 10^{6}$ & $2 \times 10^{6}$ \\
12 & $4.5 \times 10^{6}$ & $5.6 \times 10^{6}$ & $1.0 \times 10^{6}$ & $6.7 \times 10^{6}$ \\
Mean & $4.0 \times 10^{6}$ & $2.3 \times 10^{6}$ & $3.2 \times 10^{6}$ & $4.0 \times 10^{6}$ \\
\hline
\end{tabular}

Table 2. Frequency of Occurrence of the Fungal Isolates.

\begin{tabular}{llllll}
\hline Place of sample collection & & & & & \\
\hline Fungal Isolate & Terminus & Faringada & Angwa Rukuba & Gada biyu & Total of specie \\
\hline A. flavus (\%) & $3(25.0)$ & $7(58.3)$ & $5(41.7)$ & $2(16.6)$ & 17 \\
A. fumigatus (\%) & $1(8.3)$ & $2(16.7)$ & $4(33.3)$ & $2(16.6)$ & 9 \\
A. parasiticus (\%) & - & $2(16.7)$ & $2(16.7)$ & $1(8.3)$ & 5 \\
A. niger (\%) & $2(16.7$ & $1(8.3)$ & $4(33.3)$ & $1(8.3)$ & 8 \\
P. chrisogenu (\%) & $2(16.7)$ & $4(33.3)$ & $4(33.3)$ & $1(8.3)$ & 11 \\
V. leceanii (\%) & $1(8.3)$ & $5(41.7)$ & $7(58.3)$ & $10(83.3)$ & 23 \\
R. oryzea (\%) & - & $7(58.3)$ & $1(8.3)$ & $2(16.7)$ & 17 \\
F. sporotrichoides (\%) & $1(8.3)$ & $1(8.3)$ & $2(16.7)$ & - & 4 \\
Yeast (\%) & $6(50.0)$ & $3(25.0)$ & $1(8.3)$ & $8(66.7)$ & 18 \\
Total & 16 & 32 & 37 & 27 & \\
\hline
\end{tabular}

Table 3. Screening for Aflatoxigenic Fungi.

\begin{tabular}{llll}
\hline $\begin{array}{l}\text { Fungal } \\
\text { Isolates }\end{array}$ & No. of Isolates & $\begin{array}{l}\text { No. of + ve } \\
\text { Samples (\%) }\end{array}$ & $\begin{array}{l}\text { No. of - ve } \\
\text { Samples (\%) }\end{array}$ \\
\hline A. flavus & 17 & $2(11.8)$ & $15(88.2)$ \\
A. fumigatus & 9 & $1(11.1)$ & $8(88.9)$ \\
A. parasiticus & 5 & $0(0.00)$ & $5(100)$ \\
A. niger & 8 & $1(12.5)$ & $7(87.5)$ \\
\hline
\end{tabular}

\section{Discussion}

This study revealed that the Bush mango seed (I. gabonensis) sold in the market in Jos metropolis are contaminated with fungal species at significant total fungal load. This could be attributed to poor handling during harvest and transportation, poor storage, and exposure in the market as observed from the sellers (Shaltout et al., 1999). Bosco F. and Mollea C. (2002) have also reported that raw materials, food and feeds are naturally susceptible to aflatoxigenic contaminants.

The study also showed contamination of Bush mango seeds sold with Jos metropolis with more than one genus of fungi. The genera implicated are Aspergillus species, Rhizopus species, Penecillium species, Fusarium species and Yeast. Most of these species have been reported to be pathogenic (Shanthini et al., 2003). Aspergillus species such as A. flavus, A. parasiticus, A. niger and A. fumigatus which were also isolated in this research are the most dangerous of all the isolates. This is due to their high aflatoxin producing pontentials and other mycotoxins of high health significance
(Adebajo, 1992; Olayemi et al., 2012).

Fungal contaminants might be killed by heat during processing but the mycotoxins can remain undestroyed in the final product thereby posing health hazard to consumers (Smith et al., 1994). The study confirmed the presence of 4 strain with aflatoxin producing potential. Subsequent exposure and as time goes on, more of the aflatoxigenic mould will proliferate on the I. gabonensis seeds and will cause more harm to consumers. Incidentally, bush mango seeds are highly consumed in plateau state. Therefore nonchalant attitude of government, non-governmental organizations and the masses toward handing practices of food and ingredients sold in open market is a pointer to severe outbreak of food diseases and poisoning in the future.

\section{Conclusion}

The Irvingia gabonensis (Bush Mango) seeds sold within Jos metropolis market were contaminated with varying levels of fungal loads from $1.0 \times 10^{6} \mathrm{cfu} / \mathrm{g}$ to $6.8 \times 10^{6} \mathrm{cfu} / \mathrm{g}$ which is alarming. A. flavus, A. fumigatus and A. niger isolated exhibited aflatoxin producing potentials. Other fungi isolated include Penecillium chrisogenu, Verticelium leceanii, Rhizopus oryzea, Fusarium sporotrichoides and yeast. This study therefore suggest that I. gabonensis (Bush Mango) seeds are susceptible to contamination by aflatoxigenic mould. 


\section{References}

[1] Adebajo LO. Spoilage moulds and aflatoxins from poultry feeds. Die Nahrung, 1992; 36(6):523-529.

[2] Barnett HL, Hunter BB. Illustrated Genera of Imperfect Fungi. 4th ed APS Press, St. Paul, Minnesota, USA. 1998; 218.

[3] Becer, U. K., \& Filazi, A. (2010). Aflatoxins, Nitrates and Nitrites Analysis In TheCommercial Cat And Dog Foods. Fresenius Environmental Bulletin, 18(11), 2523-2527.

[4] Bosco, F., \& Mollea, C. (2012). Mycotoxins in Food. In: Valdez B. (ed), Food Industrial Processes- Methods and Equipment, InTech, 169-200, Available from, http://www.intechopen.com/books/food-industrial-processesmethods-and-equipment, (accessed 13 May 2012).

[5] cdn.intechopen.com/pdfs/20401/InTechAflatoxins_contamination_analysis (accessed 13 May 2012).

and_control.pdf,

[6] Davis ND, Iyer SK, Diener UL. Improved method of screening for aflatoxin with a coconut agar medium. Appl. Environ. Microb. 1987; 53: 1593-1595.

[7] Dors, G. C., Caldas, S. S., Feddern, V., Bemvenuti, R. H., Hackbart, H. C. S., Souza, M. M., Oliveira, M. S., GardaBuffon, J., Primel, E. G., \& Badiale-Furlong, E. (2011). Aflatoxins: Contamination, Analysis and Control. In GuevaraGonzález RG. (Ed), Aflatoxins- Biochemistry and Molcecular Biology, InTech, 415-438, Available from, http://
[8] Hussein, H. S. and Brasel, J. M. (2001). Toxicity, metabolism and impact of mycotoxin on human and animals. Toxicology, 167: 101-134.

[9] Miller, J. D., Beardall, J. M. (1994). In Miller, J. D. and Trenholm H. L. (Eds). Mycotoxins in grains: compounds other than aflatoxin. Eagan press. St. Paul, Minnesota USA. Pp. 487-593.

[10] Negedu, A., Atawodi, S. E., Ameh, J. B., Umoh, V. J., \& Tanko, H. Y. (2011). Economic and Health Perspectives of Mycotoxins: A Review. Continental Journal of Biomedical Sciences, 5(1), 5-26.

[11] Okafor, J. C. (1978). Development of forest tree crops for food supplies to Nigeria. Forest Ecology Management 17: 111.

[12] Olayemi FF, Raji AO, Adedayo MR. Microbiological quality of catfish (Clarias gariepinus) smoked with Nigerian Stored Products Research Institute (NSPRI) developed smoking kiln. Inter. Res. J. Microb. 2012; 3(13):426-430.

[13] Shaltout FA, Edris AM. Contamination of shawerma with pathogenic yeasts. Assiut Vet. Med. J. 1999; 41:170-176.

[14] Shanthini CF, Patterson J. Fungi in salted and dried fish of Tuticorin, Southeast coast of India. Fisheries Technologists, Cochin. India. 2003; 412-417.

[15] Shuaib, F. M. B., Ehiri, J., Abdullahi, A., Williams, J. H., \& Jolly, P. E. (2010). Reproductive health effects of aflatoxins: A review of the literature. Reproductive Toxicology, 29, 262-270. 